\title{
Response of direct dry seeded rice (Oryza sativa L.) to seeding dates and seed rates
}

\author{
JD Rangit ${ }^{1}, \mathrm{~S}$ Sharma ${ }^{2}$ and DD Gautam ${ }^{1}$ \\ ${ }^{1}$ Agronomy Division, Khumaltar, NARC \\ ${ }^{2}$ Plant Pathology Division, Khumaltar, NARC
}

\begin{abstract}
Field studies to access seed rate, seeding dates, and weed infestation in direct dry sseded rice (Khumal -4) were carried out under rice-wheat rotation system at Khumaltar during 2005/06 -2007/08. The broadleaf weeds: Ageratum conyzoides, Commelina diffusa, Eclipta prostrata, Amaranthus veridis, Coronopus didymus, Lactuca sp. the grassy weeds: Echinochloa colona, Cynodon dactylon, and Paspalum distichum and the sedges: Cyperus difformis and $C$ iria were recorded. E colona was the dominant weed in the second year, however $A$ conyzoides was pronounced in the first year. A conyzoides showed an increasing trend over years and became a dominant species ranging from $2-13 / 0.25 \mathrm{~m}^{2}$ in the 1 st year and $53-144 / 0.25 \mathrm{~m}^{2}$ in the $3^{\text {rd }}$ year. Significant interaction effect on total weed number/ $0.25 \mathrm{~m}^{2}$ was recorded in the $2^{\text {nd }}$ seeding date in all seed rates. Significantly higher weed numbers were recorded in $2^{\text {nd }}$ seeding date and $20 \mathrm{~kg} / \mathrm{ha}$ seed rate in the $3^{\text {rd }}$ year. There was no significant interaction between different seed rate and seeding date on the gall formation due to Meloidogyne graminicola. Plant height, tillers $/ \mathrm{m}^{2}$, number of seeds/panicle, and grain yield were not significantly affected due to seeding dates except plant height in 2005/06. Number of tillers/ $\mathrm{m}^{2}$ was significantly different among seed rates and showed slightly increasing trend with higher seed rates. But there was no significant different in grain yield among seed rates except in the year 2005/06. Dry straw weight did not show consistent results among seeding dates. The present study showed that rice seeding can be done in mid May with the seed rates $30-50 \mathrm{~kg} / \mathrm{ha}$.
\end{abstract}

Key words: Weed, tillage, seed, date, yield

\section{Introduction}

Rice transplanting is the main method of rice culture throughout Nepal. It's a traditional method and the farmer's are practicing from time immemorial. Rice transplanting is sometimes taken as a good occasion for social gathering with happiest mood and singing in the field. This method is quite good as it minimize many initial weeds due to piddling. But this practice is becoming very expensive because of labor scare during pick transplanting seasons. Studies had shown that soil texture will not be detoriated in non puddled soil compared to continuous puddled soil. It also minimizes the emissions of methane gas compared to transplanted rice fields. Puddling for rice transplanting also makes land preparation difficult for wheat crop in rice- wheat rotation resulting in cloddy soil structure, loss of soil moisture, delayed and inadequate seed soil contact (Sharma and De Datta, 1985).Weeds are one of the limiting factors in direct seeded rice in reducing the yield. Weed account for 50-80\% yield reduction in rainfed uplands (Ranjit et al., 1989; Sinha et al., 1996). The yield losses caused by different weeds depend on the type of rice culture, weed infestation, density and weed species prevalent such as Cyperus difformis (12-50\%), Cyperus iria (40\%), Cyperus rotundus (50\%), Echinochloa colona (85\%), E. crusgalli (100\%), Fimbristylis littoralis (50\%), Leptochloa chinesis (40\%), Monochoria vaginalis (85\%), and $P$ distichum (45\%) (Ampong and De Datta, 1991). 
Hand weeding is the most popular weeding method in Nepal as well as in many parts of the world. Besides hand pulling and hand weeding, a number of herbicides have been developed and tested for the direct seeded rice around the world. Herbicides such as butachlor, thiobencarb, pendimethalin, oxyfluorfen, propanil, quinclorac, ioxynil, 2,4-D, piperophos + sulfonylurea, bentazone, molinate, anilophos and nominee have been tested in direct seeded rice in the past research (Biswas et al., 1992; Crawford and Jordan, 1995; Ranjit et al., 1989; Ranjit and Suwanketnikom, 2005). Many factors and agroecological regions affect change of weed flora. Weed flora in the rainfed ecosystem have been reported most complex compared to irrigated rice, but the weed management is most important and can be filled up at least 15\% yield gap in different growing conditions (Moody, 1982). Though transplanting is a common practice of rice seeding throughout Nepal, but direct seeding is getting importance due to social and economic factors such as there is no drudgery for land preparation, raising seedlings and transplanting. The looming water crisis and increasing labor cost inducing researchers to find out alternate ways of rice seeding. Direct seeding of germinating or dry seed is one of the alternatives to transplanting. But the appropriate plating methods depend on agro ecological region, soil type as well as cropping systems.

Direct seeding might become popular in the coming days among the farmers as it is economical compared to transplanting. Past studies showed that yields are comparable with transplanted rice if crop is properly managed. Direct seeded rice (DSR) matures early than transplanted rice (TPR) but weeds become a constraint factor. Depending on the level of weed infestation in dry seeded rice the seed rate should also be increased. However, if conditions for rice seed germination and subsequent operations are favorable, the seed rate for dry seeding could be reduced (Farooq et al., 2006). There is no optimum seed rate for unweeded situation which was conducted with seed rates from $20-120 \mathrm{~kg} / \mathrm{ha}$. Any seed rate can be used in direct seeded rice depending on weed control practices used. Low seeding rate can be used because of plant compensation at later growth stages provided weed control is carried out. But best solution is to use seed rate at $60-80 \mathrm{~kg} / \mathrm{ha}$ (Azmi, 1997). Studies on varietals performance were initiated in midhills with only one seed rate of $50 \mathrm{~kg} / \mathrm{ha}$ (Ranjit et al., 2008). Direct dry seeding could be done by various methods such as broadcasting, Chinese seed drill, raised seed bed and manually (Annual report, 2005/06). Weed weight was affected by cultivars; row spacing or seed rates up to $160 \mathrm{~kg} / \mathrm{ha}$ (Moody, 1982). Direct seeding is one of the resource conservation techniques too. It saves time and resource compared to transplanting. It avoids drudgery of land preparation, seedling raising and transplanting. It also saves water volume which is essential for puddling. Hence, research on direct dry seeding has been initiating since many years in Agronomy Division, Khumaltar, midhills condition of Nepal. But it is realized the lack of studies on seeding dates and seed rates for direct dry seeding environment. The objective of the study was to asses seeding dates and seed rates for direct dry seeded rice.

\section{Methodology}

Field studies on seeding dates and seed rates in direct dry seeded rice were initiated in rice - wheat systems in the same field during three years (2005/06 (2062/63), 2006/07 (2063/64), and 2007/08 (2064/65). The experiment was laid out in split plot design with minimum tillage (one pass by Chinese hand tractor) in the $2^{\text {nd }}$ and $3^{\text {rd }}$ year. The gross plot size was $3 \mathrm{~m} \mathrm{x} 4 \mathrm{~m}\left(12 \mathrm{~m}^{2}\right)$ with $20 \mathrm{~cm}$ row-to-row spacing .The main plot consists of 3 seeding dates (May 16, May 26 and June 5) and sub-plot consists of 5 seed rates $(20,30,40,50$, and $60 \mathrm{~kg} / \mathrm{ha})$. Khumal-4 rice variety was used for this study. Chemical fertilizer was applied at 100:40:30 NPK kg/ha. Chemical fertilizer at 20:40:30 NPK kg/ha was applied during planting as basal. Rest dose of nitrogen was given in 2 split doses as 40:0:0 NPK kg/ha at tillering stage and 40:0:0 NPK kg/ha at panicle initiation stage. Butachlor @ 21/ha was sprayed within 3 days of 
rice seeding plus one hand weeding after 35-40 days of seeding to manage the weeds. Weeds were recorded from $0.25 \mathrm{~m}^{2}$ quadrat after 35-40 days of seeding. Gall formation due to Meloidogyne graminicola was also recorded.. Plant height, tillers $/ \mathrm{m}^{2}$, grains per panicle, thousand seed weight, and yield were recorded. Maximum, minimum temperature and rainfall were recorded during the experiment period.

Treatment combinations

\begin{tabular}{lc}
\hline \multicolumn{1}{c}{ Main-plot; Date of seeding } & Sub-plot; Seed rates \\
\hline May 16 (Jestha 02) & $20 \mathrm{~kg} / \mathrm{ha}$ \\
May 26 (Jestha 12) & $30 \mathrm{~kg} / \mathrm{ha}$ \\
June 05 (Jestha 22) & $40 \mathrm{~kg} / \mathrm{ha}$ \\
& $50 \mathrm{~kg} / \mathrm{ha}$ \\
& $60 \mathrm{~kg} / \mathrm{ha}$ \\
\hline
\end{tabular}

\section{Result and discussion}

\section{Treatment effect on weeds}

Main weed species recorded from the experimental field are given in Table 1. Ageratum conyzoides, Commelina diffusa, Eclipta prostrata, Amaranthus veridis, Coronopus didymus, and Lactuca sp. were among the broadleaf while Echinochloa colona, and Cynodon dactylon were among the grass and similarly sedges were Cyperus difformis and $C$ iria.

\section{Weed trend}

Among these weeds, $E$ colona and $A$ conyzoides were the main weeds in the experimental field. The number $E$ colona was higher than $A$ conyzoides in the beginning of the experiment. But $A$ conyzoides showed an increasing trend over years and became a dominant species ranging from $2-13 / 0.25 \mathrm{~m}^{2}$ in the 1 st year and $51-109 / 0.25 \mathrm{~m}^{2}$ in the $3^{\text {rd }}$ year (Fig. 1). Significant interaction effect on total weed number/ $0.25 \mathrm{~m} 2$ was recorded in the $2^{\text {nd }}$ seeding date (May 26) in all seed rates. Significantly higher total weed numbers were recorded on May 26 seeding date and $20 \mathrm{~kg} / \mathrm{ha}$ seed rate in the $3^{\text {rd }}$ year. Cyperus $\mathrm{sp}$ population showed a stable trend. The population did not increase over years. The number of grass weed decreased in the $3^{\text {rd }}$ year. Broadleaf weed showed an increasing trend over year. It has been expected that the major weed problem in R-W system in mid hill during summer season were annual grasses and sedges (Mallik, 1998). There were no significant differences in weed population in different seed rates during the $2005 / 06$ and 2006/07. But in the $3^{\text {rd }}$ year the weeds were significantly higher in the $2^{\text {nd }}$ date of seeding (Table 1).There was no consistent difference of weed population in the $1^{\text {st }}$ two years among the seed rates and seeding dates. But in the $3^{\text {rd }}$ year broadleaf especially $A$ conyzoides showed differences among seeding dates and seed rates. The number of this weed was higher in $2^{\text {nd }}$ date of seeding and low seed rate of $20 \mathrm{~kg} / \mathrm{ha}$.The increased number of $A$ conyzoides over years might be due to favorable conditions for emergence and growth. Total number of weeds also showed an increasing trend over time. The number was significantly different in the $3^{\text {rd }}$ year for both seeding dates and seed rates. Lower seed rate has more weeds. It might be due favorable condition and spacing for growth of weeds, though $A$ conyzoides was the major one among the total weeds. 
Table 1. Weed species in date and seed rate at Khumaltar

\begin{tabular}{|c|c|c|c|c|}
\hline Weed species & Vernacular name & $2005 / 06$ & $2006 / 07$ & $2007 / 08$ \\
\hline \multicolumn{5}{|l|}{ Broadleaf } \\
\hline Ageratum conyzoides & Gandhe & $\sqrt{ }$ & $\sqrt{ }$ & $\sqrt{ }$ \\
\hline Alteranthera alternifolia & & $\sqrt{ }$ & - & \\
\hline Amaranthus sp & Mothe & $\sqrt{ }$ & - & \\
\hline Coronopus didymes & Chamsure jhar & - & $\sqrt{ }$ & $\sqrt{ }$ \\
\hline Commelina diffusa & Kane & $\sqrt{ }$ & $\sqrt{ }$ & $\sqrt{ }$ \\
\hline Cardamine pretense & & - & - & \\
\hline Eclipta prostrate & Bhringraj & $\sqrt{ }$ & $\sqrt{ }$ & $\sqrt{ }$ \\
\hline Lactuca sp & Dudhe & - & $\sqrt{ }$ & \\
\hline Lindernia $s p$ & & - & $\sqrt{ }$ & $\sqrt{ }$ \\
\hline Stellaria media & Armale & - & $\sqrt{ }$ & \\
\hline Solanum nigrum & Kaligedi & & & $\sqrt{ }$ \\
\hline \multicolumn{5}{|l|}{ Grass } \\
\hline Cynodon dactylon & Dubo & $\sqrt{ }$ & $\sqrt{ }$ & $\sqrt{ }$ \\
\hline Digitaria adcendens & Chitre Banso & $\sqrt{ }$ & $\sqrt{ }$ & \\
\hline Echinochloa colona & Sanwa & & & $\sqrt{ }$ \\
\hline \multicolumn{5}{|l|}{ Sedges } \\
\hline Cyperus sp & Mothe & & & $\sqrt{ }$ \\
\hline Cyperus iria & “ & & $\sqrt{ }$ & \\
\hline Cyperus differmis & “ & $\sqrt{ }$ & - & \\
\hline
\end{tabular}

It is hard to conclude whether decreased number of $E$ colona was because of the application of Butachlor or affect of seeding dates and rates. It needs further study to confirm this cause.

Response of yield attributes to date of seeding and seed rates

\section{Plant height}

Plant height in different seeding dates and seed rates showed the same range except in the $1^{\text {st }}$ year. Comparatively plant height was less in the $1^{\text {st }}$ year thought the variety was the same (Table 2 ). The season for this is not known. But it is difficult to conclude whether it was due to differences in rainfall patterns. Rainfall was less in the beginning of the rice growth in the $1^{\text {st }}$ year than in the $2^{\text {nd }}$ and $3^{\text {rd }}$ year.

\section{Tillers per meter square}

The number of tillers was not significantly affected by seeding dates in all tested years. But the tiller number was comparatively higher $\left(339-378 / \mathrm{m}^{2}\right)$ in the $3^{\text {rd }}$ seeding date (June 05) in last two years. It showed that seeding dates have not much effected on tiller number (Table 2). Tillers $/ \mathrm{m}^{2}$ were significantly high $\left(289-370 / \mathrm{m}^{2}\right)$ in high seed rate $(60 \mathrm{~kg} / \mathrm{ha})$ and less $\left(225-270 / \mathrm{m}^{2}\right)$ in low seed rate $(20$ $\mathrm{kg} / \mathrm{ha})$.

\section{Thousand grain weight}

Thousand grain weights were also not affected by seeding date and seed rates except in $2^{\text {nd }}$ year. 1000 grain weight ranged from 17.9 to $19.9 \mathrm{~g}$.

\section{Grains/panicle}

Grains per panicle did not show consistent result over years. Grains per panicle were not affected due to different seeding dates and increasing seed rates. However, filled grains /panicle were more in low seed rate $(20 \mathrm{~kg} / \mathrm{ha})$. It might be due to less competition among the rice population and ultimately less sharing of inputs (Table 2). 
Table 2 Effect of seeding dates and seed rates on weeds, and yield attributes of direct dry seeded rice in Khumaltar 2005/06 to2007/08

\begin{tabular}{|c|c|c|c|c|c|c|c|c|c|c|c|c|c|c|c|c|}
\hline \multirow{2}{*}{$\begin{array}{c}\text { Treatments } \\
\text { Date of seeding ( D) }\end{array}$} & \multicolumn{4}{|c|}{ \# of weeds / $0.25 \mathrm{~m}^{2}$ ) } & \multicolumn{4}{|c|}{ Plant height $(\mathrm{cm})$} & \multicolumn{4}{|c|}{ \# of Tiller/ $\mathbf{m}^{2}$} & \multicolumn{4}{|c|}{1000 seed weight $(\mathrm{g})$} \\
\hline & $05 / 06$ & $06 / 07$ & 07/08 & Mean & $05 / 06$ & $06 / 07$ & $07 / 08$ & Mean & $05 / 06$ & $06 / 07$ & 07/08 & Mean & $05 / 06$ & $06 / 07$ & $07 / 08$ & Mean \\
\hline May 16 (Jestha 02) D1 & 29 & 83 & $59 \mathrm{~b}$ & 47 & $\begin{array}{r}114 \\
b\end{array}$ & 124 & 124 & 121 & 286 & 284 & 297 & 289 & 17.9 & 19.2 & 19.4 & 18.8 \\
\hline May 26 (Jestha 12) D2 & 35 & 88 & $155 \mathrm{al}$ & 93 & $118 \mathrm{al}$ & 121 & 122. & 120 & 263 & 290 & 279 & 277 & $\begin{array}{r}17 . \\
9\end{array}$ & 19.2 & $\begin{array}{c}19 . \\
9\end{array}$ & 19.0 \\
\hline $\begin{array}{l}\text { June } 05 \text { (Jestha 22) D3 } \\
\text { Seed rate }(\mathbf{R})\end{array}$ & 31 & 69 & $49 \mathrm{a}$ & 50 & $123 \mathrm{a}$ & 123 & 127 & 124 & 233 & 378 & 338 & 316 & 18.2 & 18.9 & 19.8 & 18.9 \\
\hline $20 \mathrm{~kg} / \mathrm{ha} \mathrm{R} 1$ & 44 & 77 & $\begin{array}{c}127 \\
\mathrm{a}\end{array}$ & 83 & 118 & $\begin{array}{c}126 \\
\mathrm{a}\end{array}$ & 125 & 123 & $\begin{array}{c}225 \\
\mathrm{c}\end{array}$ & $\begin{array}{c}245 \\
c\end{array}$ & 274 & 248 & 18.0 & $18.7 \mathrm{c}$ & 19.9 & 18.7 \\
\hline $30 \mathrm{~kg} / \mathrm{ha} \mathrm{R} 2$ & 27 & 76 & $87 \mathrm{~b}$ & 63 & 118 & $\begin{array}{c}126 \\
a\end{array}$ & 124 & 123 & $242 b_{r}$ & $\begin{array}{r}274 \\
\mathrm{bc}\end{array}$ & 290 & 269 & 18.0 & $\begin{array}{l}19.2 \\
\mathrm{abc}\end{array}$ & 19.6 & 18.9 \\
\hline $40 \mathrm{~kg} / \mathrm{ha} \mathrm{R} 3$ & 29 & 77 & $70 \mathrm{~b}$ & 59 & 119 & $\begin{array}{l}123 \\
\mathrm{ab}\end{array}$ & 124 & 122 & $278 \mathrm{a}$ & $\begin{array}{c}333 \\
\mathrm{c}\end{array}$ & 272 & 294 & 17.9 & $18.8 \mathrm{t}$ & 19.7 & 18.8 \\
\hline $50 \mathrm{~kg} / \mathrm{ha} \mathrm{R} 4$ & 28 & 75 & $68 \mathrm{~b}$ & 57 & 117 & $\begin{array}{c}117 \\
\mathrm{c}\end{array}$ & 126 & 120 & $\begin{array}{l}269 \\
\text { abc }\end{array}$ & $\begin{array}{l}366 \\
a b\end{array}$ & 328 & 321 & 17.9 & $19.3 \mathrm{a}$ & 19.7 & 18.8 \\
\hline $60 \mathrm{~kg} / \mathrm{ha} \mathrm{R} 5$ & 31 & 94 & $87 \mathrm{~b}$ & 71 & 121 & $\begin{array}{l}121 \\
b c\end{array}$ & 124 & 122 & $\begin{array}{c}289 \\
\mathrm{a}\end{array}$ & $\begin{array}{c}370 \\
\mathrm{a}\end{array}$ & 362 & 340 & 18.0 & $19.4 \mathrm{a}$ & 19.6 & 19.0 \\
\hline Date of seeding (D) & - & - & 54 & & 6 & - & - & & - & - & - & & - & - & - & \\
\hline Seed Rate ${ }^{\circledR}$ & - & - & 31 & & - & 4.5 & - & & 44 & 74 & 51 & & - & 0.49 & - & \\
\hline $\mathrm{D} \times \mathrm{R}$ & - & - & 53 & & - & - & - & & - & - & - & & - & - & - & \\
\hline $\mathrm{cv} \%$ & 49 & 42 & 35 & & 4 & 4 & 9 & & 18 & 24 & 17 & & 2.3 & 2.7 & 1.9 & \\
\hline
\end{tabular}

Mean followed by same letter in a column are not significantly different at $\mathrm{P}<0.05$

\section{Grain yield}

Grain yield was not significantly affected by seeding dates. Comparatively fewer yields were recorded in the $2^{\text {nd }}$ year than in $1^{\text {st }}$ and $3^{\text {rd }}$ year. Tillers $/ \mathrm{m}^{2}$ also did not affect to rice yield (Table 3 ). Significantly different grain yield due to seed rate was recorded in the $2^{\text {nd }}$ year. Rest of other seed rates gave comparable yield. Though, grain yield was not significantly different among the seed rates in $2^{\text {nd }}$ and $3^{\text {rd }}$ year, but less grain yield was recorded in lower seed rate $(20 \mathrm{~kg} / \mathrm{ha})$ in all years. Though the seed rates had not much affect on grain yield, but still $30-60 \mathrm{~kg} / \mathrm{ha}$ seed rates gave higher grain yield than that of 20 $\mathrm{kg} / \mathrm{ha}$. Interaction effect also showed low grain yield in $20 \mathrm{~kg} / \mathrm{ha}$ seed rate in all dates (Table 3 ).

Table 3. Effect of seeding dates and seed rates on yield attributes of dry direct seeded rice in Khumaltar $2005 / 06(2062 / 63)$ to $2007 / 08(2064 / 65)$

\begin{tabular}{|c|c|c|c|c|c|c|c|c|c|c|c|c|c|c|c|c|}
\hline \multirow{3}{*}{$\begin{array}{c}\text { Treatments } \\
\text { Date of } \\
\text { seeding ( D) }\end{array}$} & \multicolumn{7}{|c|}{ \# Seeds/panicle } & \multirow{2}{*}{\multicolumn{5}{|c|}{$\frac{\text { Grain Yield }}{\text { (kg/ha) }}$}} & \multirow{2}{*}{\multicolumn{4}{|c|}{$\begin{array}{c}\text { Dry straw } \\
(\mathrm{kg} / \mathrm{ha})\end{array}$}} \\
\hline & & Fill & & & & Unfilled & & & & & & & & & & \\
\hline & $05 / 06$ & $\begin{array}{r}06 / 0 \\
7\end{array}$ & 07/08 & $\begin{array}{l}\text { Me } \\
\text { an }\end{array}$ & $05 / 06$ & 06/07 & 07/08 & Mean & $05 / 06$ & 06/07 & 07/08 & Mean & $\begin{array}{c}05 / 0 \\
6\end{array}$ & $06 / 07$ & 07/08 & Mena \\
\hline $\begin{array}{l}\text { May } 16 \\
\text { (Jestha 02) } \\
\text { D1 }\end{array}$ & 122 & 154 & 126 & $\begin{array}{c}13 \\
4\end{array}$ & 8 & 12 & 7 & 9 & 4287 & 3932 & 4763 & 4327.3 & 6670 & $6789 \mathrm{~b}$ & $7873 \mathrm{a}$ & 7110.7 \\
\hline $\begin{array}{l}\text { May } 26 \\
\text { (Jestha 12) } \\
\text { D2 }\end{array}$ & 132 & 135 & 114 & $\begin{array}{c}12 \\
7\end{array}$ & 6 & 11 & 13 & 10 & 4733 & 3920 & 4350 & 4334.3 & 6573 & $9137 \mathrm{a}$ & $6277 \mathrm{~b}$ & 7329 \\
\hline $\begin{array}{l}\text { June } 05 \\
\text { (Jestha 22) } \\
\text { D3 } \\
\text { Seed rate } \\
\text { (R) }\end{array}$ & 133 & 147 & 119 & $\begin{array}{c}13 \\
3\end{array}$ & 6 & 11 & 11 & 9 & 4429 & 4077 & 5190 & 4565.3 & 6545 & $\begin{array}{c}11224 \\
\mathrm{a}\end{array}$ & $7723 \mathrm{~b}$ & 8497.3 \\
\hline 20 kg/ha R1 & 139 & $\begin{array}{c}166 \\
\mathrm{a}\end{array}$ & 122 & $\begin{array}{c}14 \\
2\end{array}$ & 8 & $16 \mathrm{a}$ & 13 & 12 & $\begin{array}{r}3964 \\
\mathrm{c}\end{array}$ & 3642 & 4649 & 4085 & 5352 & $7510 \mathrm{c}$ & 6653 & 6505 \\
\hline 30 kg/ha R2 & 131 & $\begin{array}{c}154 \\
\mathrm{ab}\end{array}$ & 119 & $\begin{array}{c}13 \\
5\end{array}$ & 7 & $11 \mathrm{~b}$ & 11 & 10 & $\begin{array}{c}4582 \\
\mathrm{ab}\end{array}$ & 4090 & 4678 & 4450 & 6766 & $\begin{array}{c}8442 \\
\text { bc }\end{array}$ & 7106 & 7438 \\
\hline 40 kg/ha R3 & 134 & $\begin{array}{c}142 \\
b c\end{array}$ & 132 & $\begin{array}{c}13 \\
6\end{array}$ & 8 & $10 \mathrm{~b}$ & 12 & 10 & $\begin{array}{c}4291 \\
b c\end{array}$ & 4202 & 4997 & 4496.7 & 6436 & $\begin{array}{c}9461 \\
\mathrm{ab}\end{array}$ & 7108 & 7668.3 \\
\hline $50 \mathrm{~kg} / \mathrm{ha}$ R4 & 120 & $\begin{array}{c}130 \\
\mathrm{c}\end{array}$ & 112 & $\begin{array}{c}12 \\
1\end{array}$ & 6 & $10 \mathrm{~b}$ & 11 & 9 & $\begin{array}{c}4563 \\
a b\end{array}$ & 3906 & 4680 & 4383 & 6853 & 9559 a & 7927 & 8119 \\
\hline
\end{tabular}




\begin{tabular}{|c|c|c|c|c|c|c|c|c|c|c|c|c|c|c|c|c|}
\hline \multirow{3}{*}{$\begin{array}{c}\text { Treatments } \\
\text { Date of } \\
\text { seeding ( D) }\end{array}$} & \multicolumn{7}{|c|}{ \# Seeds/panicle } & \multicolumn{5}{|c|}{ Grain Yield } & \multirow{2}{*}{\multicolumn{4}{|c|}{$\begin{array}{c}\text { Dry straw } \\
\text { (kg/ha) }\end{array}$}} \\
\hline & & Fill & & & & Unfilled & & & & $\overline{\text { (kg/ha) }}$ & & & & & & \\
\hline & $05 / 06$ & $\begin{array}{r}06 / 0 \\
7\end{array}$ & 07/08 & $\begin{array}{l}\text { Me } \\
\text { an }\end{array}$ & $05 / 06$ & 06/07 & 07/08 & Mean & $05 / 06$ & $06 / 07$ & 07/08 & Mean & $\begin{array}{c}05 / 0 \\
6\end{array}$ & $06 / 07$ & $07 / 08$ & Mena \\
\hline $60 \mathrm{~kg} / \mathrm{ha} \mathrm{R} 5$ & 120 & $\begin{array}{l}134 \\
\mathrm{bc}\end{array}$ & 112 & $\begin{array}{c}12 \\
2\end{array}$ & 6 & $12 \mathrm{ab}$ & 7 & 8 & $\begin{array}{c}5015 \\
\mathrm{a}\end{array}$ & 4042 & 4824 & 4627 & 7573 & $\begin{array}{c}10278 \\
\mathrm{a}\end{array}$ & 7660 & 8503.7 \\
\hline Date of & - & - & - & & - & - & - & & 5 & - & - & & - & 2131 & 86 & \\
\hline Seed Rate $®$ & - & - & - & & - & - & - & & - & - & - & & - & - & - & \\
\hline $\begin{array}{l}\mathrm{D} \times \mathrm{R} \\
\mathrm{cv} \%\end{array}$ & 17 & 16.9 & 15 & & 40 & 36.4 & 54 & & 13 & 11.2 & 11 & & 21 & 12.4 & 15 & \\
\hline
\end{tabular}

Mean followed by same letter in column are not significantly different at $P<0.05$

\section{Dry straw weight}

Dry straw weight did not show consistent result among seeding dates. But increasing trend of straw weight was recorded among seed rates. Dry straw wt. was higher in the $2^{\text {nd }}$ year increasing trend was recorded with seed dates. Higher seed rate same more straw yield than lower seed rate. However, 60 $\mathrm{kg} / \mathrm{ha}$ seed rate same higher straw yield than others in all the years. There was no significant interaction between different seed rates \& seeding dates on the gall formation due to Meloidogyne graminicola (Table 4).

Table 4. Effect of date of seeding with respect to different seed rate on the gall formation due to Meloidogyne graminicola in rice field at Khumaltar.

\begin{tabular}{|c|c|c|c|c|c|}
\hline \multirow[t]{3}{*}{ Date of seeding } & \multicolumn{5}{|c|}{ Gall Index (0-10) } \\
\hline & \multicolumn{5}{|c|}{ Seed Rate (kg/ha) } \\
\hline & 20 & 30 & 40 & 50 & 60 \\
\hline 16 May & $5.19 \mathrm{a}$ & $4.60 \mathrm{a}$ & $4.81 \mathrm{a}$ & $3.92 \mathrm{a}$ & $5.07 \mathrm{a}$ \\
\hline 26 May & $4.43 a$ & $4.74 \mathrm{a}$ & $2.31 \mathrm{a}$ & $2.90 \mathrm{a}$ & $4.3 \mathrm{a}$ \\
\hline 05 June & $4.27 \mathrm{a}$ & $2.79 \mathrm{a}$ & $2.62 \mathrm{a}$ & $5.61 \mathrm{a}$ & $4.0 \mathrm{a}$ \\
\hline CV $(\%)$ & 14.60 & 14.77 & 27.9 & 22.4 & 23.33 \\
\hline LSD $(\mathrm{P}<0.05)$ & 1.53 & 2.10 & 2.74 & 1.98 & 1.35 \\
\hline
\end{tabular}

Mean followed by same letter are not significantly different at $\mathbf{P}<0.05$ by Duncan's Multiple Range Test (DMRT).

\section{Conclusion}

All categories of grass, sedge and broadleaf weeds were recorded in the experimental field. The number of species differed over time. Among different species $A$ conyzoides and $E$ colona were the major weeds. The number of $E$ colona decreased over years. But $A$ conyzoides increased over years showing weed shift due to rice culture. The total number of weed was higher in low seed rate $(20 \mathrm{~kg} / \mathrm{ha})$ and second seeding date (26 May). There was no significant interaction between different seed rates and seeding dates and gall formation due to Meloidogyne graminicola (Sharma et al.2008). The present study showed that rice seeding can be done in mid May with seed rates $30-50 \mathrm{~kg} / \mathrm{ha}$. However, varietals performance to seed rates, weed species and environmental interaction were the researchable issues under diverse situations. Because most of the rice varieties used in the direct seeding are selected under transplanting condition. 


\section{Acknowledgements}

Authors highly appreciate Nepal Agricultural Research Council (NARC) for approving and funding for this study. They are thankful to Dr. Madhav Joshi, Chief Agronomist, Agronomy Division, Mr Suraj Vaidya, Technical officer, Plant Pathology Division, Mr. Rajan Ghimire, and Mr Uttam Thapa for their support and help throughout research period and Ms Pramila Khatri for word processing.

\section{Reference}

Ampong-Nyarko, K and SK DeDatta. 1991.A handbook for weed control in rice. International Rice research Institute. P O Box 933, Manila, Philippines, 113 p.

Annual Report. 2005/06.Agronomy Division, Khumaltar, Lalitpur, Nepal.

Azmi, M. 1997. Weed populations in direct seeded rice as affected by seeding rates. In Proceedings $16^{\text {th }}$ AsianPacific Weed Science Society Conference, Kwala Lumpur, Malaysia, 8-12 Sep. Malaysian Plant Protection Society.

Biswas, JC, SA Sattar, and SB Siddique. 1992. Evaluationn of herbicides in direct seeded rice in Bangladesh. Bangladesh Rice Journal 2(1-2): 40-43.

Crawford, SH and DL Jordan. 1995. Comparision of single and multiple applications of propanil and residual herbicides in dry seeded rice (Oryza sativa). Weed Tech. 9(1):153-157.

Farooq M, MA Basra Shahzad, and BA Saleem 2006 - Direct seeding method popular among rice farmers. DAWN the internet edition (google.com).

Moody, K. 1982. Workshop on cropping system in Asia pp. 161-177, IRRI Los Banos, Laguna Philippines.

Ranjit JD, DD Gautam, M Joshi, and HK Upreti. 2008. Rice Varieties under Direct Dry Seeding: Prospect for Resource Conservation Practices. Paper presented at Third Society of Agricultural Scientists, Nepal (SAS-N) Convention held in Khumaltar, Lalitpur, Nepal from August 27-29, 2008

Ranjit, JD and R Suwanketnikom. 2005. Response of weeds and yield of dry direct seeded rice to tillage and weed management. Kasetsart J. (Nat. Sci.) 39:165-173.

Ranjit, JD, KP Bhurer, KP Koirala, Y Thakur, and DN Choudhary. 1989. Screening of herbicides in upland and transplanted rice, pp. 129-139. In Proc. $14^{\text {th }}$ Summer crops workshop, Parwanipur, Nepal.

Sharma, P K and S K DeDatta. 1985. Effects puddling on soil physical properties and processes. In Soil Physics and rice IRRI publications.

Sharma, S, JD Ranjit, S Baidya, BR Khadge, S Joshi, and DD Gautam. 2008. Major soil and foliar disease associated with rice and wheat system . Paper presented to winter crops workshop held at Khumaltar, Lalitpur, Nepal Sep. 11-13, 2008.

Sinha, PK, CV Singh, RK Mishra, D Maiti, VD Shukla, and M Variar.1996. Rainfed upland rice - future strategies. Indian Farming 66(9): 25-29. 